\title{
Cloth face masks to prevent Covid-19 and other respiratory infections*
}

\author{
Magda Milleyde de Sousa Lima ${ }^{1,2}$ \\ (D) https://orcid.org/0000-0001-5763-8791 \\ Francisco Marcelo Leandro Cavalcante ${ }^{3}$ \\ (1) https://orcid.org/0000-0001-6143-1558 \\ Thamires Sales Macêdo ${ }^{3}$ \\ (D) https://orcid.org/0000-0002-3896-0184 \\ Nelson Miguel Galindo-Neto ${ }^{4}$ \\ (1) https://orcid.org/0000-0002-7003-165X \\ Joselany Áfio Caetano ${ }^{1,2}$ \\ (1) https://orcid. org/0000-0002-0807-056X \\ Lívia Moreira Barros 5 \\ (D) https://orcid.org/0000-0002-9763-280X
}

Objective: to analyze scientific evidence on the efficacy of cloth masks in preventing COVID-19 and other respiratory infections. Method: integrative literature review based on the following guiding question: What is the efficacy of cloth face masks in absorbing particles that cause respiratory infection? The search was conducted in eight electronic databases, without any restriction in terms of language or period. Results: low coverage cloth face masks made of $100 \%$ cotton, scarf, pillowcase, antimicrobial pillowcase, silk, linen, tea towel, or vacuum bag, present marginal/reasonable protection against particles while high coverage cloth masks provide high protection. Conclusion: cloth face masks are a preventive measure with moderate efficacy in preventing the dissemination of respiratory infections caused by particles with the same size or smaller than those of SARS-CoV-2. The type of fabric used, number of layers and frequency of washings influence the efficacy of the barrier against droplets.

Descriptors: Facial Masks; Coronavirus; Coronavirus Infections; Respiratory Tract Infections; Disease Prevention; Review.

\section{How to cite this article}

Lima MMS, Cavalcante FML, Macêdo TS, Galindo-Neto NM, Caetano JA, Barros LM. Cloth face masks to prevent Covid-19 and other respiratory infections. Rev. Latino-Am. Enfermagem. 2020;28:e3353. [Access $f$ 千 1 ]; Available in: DOI: http://dx.doi.org/10.1590/1518-8345.4537.3353. 


\section{Introduction}

Characterized as a pandemic by the World Health Organization (WHO), the emergent outbreak of COVID-19 has become a worldwide public health emergency ${ }^{(1)}$. Caused by the SARS-Cov 2 coronavirus strain, the disease originated in Wuhan, China, and rapidly disseminated across countries. Given its highly transmissible nature, it has challenged the health systems and governments to urgently implement preventive measures to contain dissemination and decrease its impact ${ }^{(2-3)}$. In May 2020, the cases confirmed worldwide surpassed 3 million, with more than 200,000 deaths ${ }^{(4)}$.

With a rapid increase in cases of the disease, interpersonal contact presented itself as a risk of infection, a situation that demanded effective adherence to preventive recommendations, such as handwashing, respiratory etiquette when coughing or sneezing, wearing masks and observing social distancing. These individual and collective measures, associated with the early identification and testing of suspected cases, are essential to decrease spreading and avoid the collapse of health systems ${ }^{(5-6)}$.

Nonetheless, the high consumption of hospital masks on the part of the population became a problem because this piece of Personal Protective Equipment (PPE) was at risk of becoming insufficient. For this reason, the Brazilian Health Regulatory Agency (ANVISA) and the WHO recommended the population to wear non-professional masks. Thus, cloth face masks became necessary due to their preventive potential, in addition to supporting a decrease in the search for hospital masks, the priority of which should be health workers providing care to severe patients ${ }^{(7-8)}$.

The adoption of cloth face masks is a public health voluntary strategic measure to contain the new coronavirus. Cloth masks represent a physical barrier that may greatly impact the combat against the pandemic and significantly contribute to decreasing the incidence of COVID-19(7). Hence, the number of people wearing cloth masks may interfere in the virus dissemination and flatten the disease's growth curve, which is relevant to favor the expansion of the health system's response capacity ${ }^{(9)}$.

Note that even though the use of cloth masks requires scientific proof of its efficacy in preventing the virus from spreading, the use of different types of masks coupled with hand washing and remaining preventive measures constitute a relevant strategy to decrease the dissemination of SARS-Cov2, considering the virus can rapidly spread through aerosols and droplets ${ }^{(10)}$.

Given this context and lack of studies addressing the efficacy of cloth face masks to prevent the new coronavirus, studies seeking evidence that support preventive measures against COVID-19 are pertinent, especially those addressing the use of cloth face masks on the part of the population, which can become coresponsible in preventing the disease. Hence, this study's objective was to analyze scientific evidence of cloth masks' efficacy in preventing COVID-19 and other respiratory infections.

\section{Method}

This integrative literature review was conducted according to the following stages: identification of the study's topic and guiding question, search for studies in the databases, critical-reflexive analysis of the studies identified, interpretation and presentation of results, and review's final synthesis ${ }^{(11)}$

Based on the Population Interest Context (PICo) $)^{(12)}$ strategy, the following guiding question was established: "How effective cloth masks are at absorbing particles that cause COVID-19 and other respiratory infections?" in which $\mathrm{P}=$ cloth mask; $\mathrm{I}=$ prevention of diseases/ absorption of particles/efficacy; and Co=respiratory infections/COVID-19.

The following databases were searched: Scopus, National Library of Medicine and National Institutes of Health (PubMed/Medline), PubMed/PMC, Web of Science, Cumulative Index of Nursing and Allied Health Literature (CINAHL), Scientific Electronic Library Online (SciELO), Cochrane and Excerpta Medica dataBASE (EMBASE). To expand the results, both conventional language and descriptors were used, such as those provided by Health Science Descriptors (DECS) and Medical Subject Headings (MeSH), by crossing: ("Cloth Mask" OR "Fabric Mask" OR "Mask" OR "Face Mask") AND "Efficacy" AND ("Respiratory Virus" OR "Influenza" OR "SARS-CoV-2" OR "Covid-19"). To fully exhaust the possibilities, the journals portal made available by the Coordination for the Improvement for Higher Education Personnel (CAPES) and accessible through the Internet Protocol (IP) coverage of the Federal University of Ceará and the State University of Acaraú was accessed.

The inclusion criterion was primary studies addressing the efficacy of cloth masks in absorbing particles. No restrictions were established for the period or language. Exclusion criteria were: dissertations, theses, literature reviews or papers not related to the study's questions, and duplicated studies.

The process of selecting papers and verifying their eligibility followed the recommendations provided by Preferred Reporting Items for Systematic Reviews and Meta-Analyses (PRISMA) ${ }^{(13)}$. First, the papers' 
titles and abstracts were read to select the papers that meet the inclusion criterion. Then, the studies selected were completed analyzed using a semi-structured instrument, which recorded the papers' title, authors, year, country, methodological characteristics, and main results. Note that three independent researchers conducted the search and selected the studies to check for potential divergences.

Level of evidence was established as follows: level I referred to meta-analyses and controlled and randomized trials; level II to experimental studies; level III to quasi-experimental studies; level IV to nonexperimental descriptive or qualitative studies; level $\mathrm{V}$ to experience reports; and level VI referred to expert opinion and consensus ${ }^{(14)}$.

This study complies with the ethical and legal principles provided by Resolution 510/2016, Brazilian Council of Health, concerning studies using information in the public domain.

\section{Results}

A total of 3,541 studies were identified, 3,447 of which were excluded for not meeting the inclusion criterion, and 84 were excluded for appearing more than once. Hence, nine studies remained in the final sample, as shown in Figure 1.

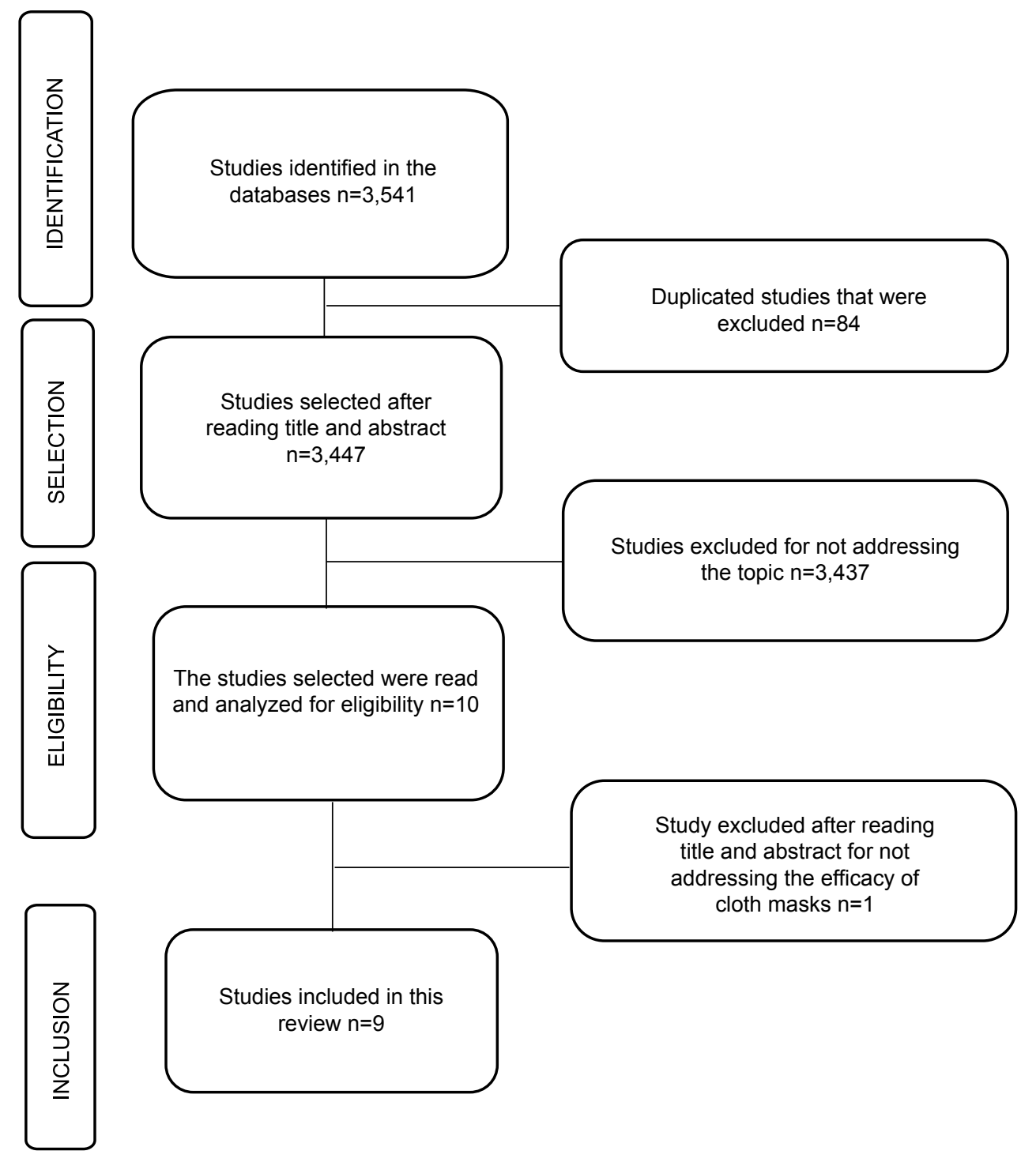

Figure 1 - Flowchart of the search and selection of studies according to PRISMA(13) guidelines. Fortaleza, CE, Brazil, 2020. 
The studies dated from 2010 to 2020, most were from 2020 (44.4\%). As for the studies' country of origin, four studies were conducted in the United States $(44.4 \%)$, two were from Nepal $(22.2 \%)$, and one was conducted in China, Vietnam, and Portugal (11.1\%), respectively. Regarding the methodological design, there was one cluster-randomized trial (11.1\%), one study adopted the mathematical analysis method proposed by Kermack-McKendrick (11.1\%), and seven studies adopted laboratory tests $(77.7 \%)$.

Figure 2 presents the nine studies selected according to author, year, country, and methodological aspects.

\begin{tabular}{|c|c|c|c|}
\hline Authors & Year/Country & Method & $\begin{array}{l}\text { Level of } \\
\text { Evidence }\end{array}$ \\
\hline Rengasamy; Eimer; Shaffer ${ }^{(15)}$ & 2010/United States & $\begin{array}{l}\text { Laboratory analysis: the performance of ordinary cloth } \\
\text { material to filter nano-size particles was tested for } \\
\text { monodisperse and polydisperse aerosols }(20-1000 \\
\left.\mathrm{nm} \text { ), at two different face speeds ( } 5.5 \text { and } 16.5 \mathrm{~cm} \mathrm{~s}^{-1}\right) \\
\text { and compared with the penetration levels for N95 } \\
\text { respirator filter media. }\end{array}$ & VI \\
\hline Davies, et al ${ }^{(16)}$ & 2013/Portugal & $\begin{array}{l}\text { Laboratory analysis: various domestic materials } \\
\text { were tested regarding their ability to block bacterial } \\
\text { and viral aerosols. The number of microorganisms } \\
\text { isolated from the cough of healthy volunteers using } \\
\text { homemade masks, surgical masks, or no masks, was } \\
\text { compared using air-sampling techniques. }\end{array}$ & VI \\
\hline Maclntyre, et $\left.a^{\mid(17}\right)$ & 2015/Vietnam & $\begin{array}{l}\text { Cluster-randomized clinical trial: the participants wore } \\
\text { masks in all the working shifts for four consecutive } \\
\text { weeks and researchers analyzed particles filtered in } \\
\text { the surface of each mask. }\end{array}$ & III \\
\hline Shakya, et al ${ }^{(18)}$ & 2016/Nepal & $\begin{array}{l}\text { Laboratory analysis: the efficiency of four types } \\
\text { of masks in absorbing five sizes of monodisperse } \\
\text { aerosols particles }(30,100 \text {, and } 500 \mathrm{~nm} \text { and } 1 \text { and } \\
2.5 \mu \mathrm{m}) \text { was tested. }\end{array}$ & VI \\
\hline Neupane, et $a^{l(19)}$ & 2019/Nepal & $\begin{array}{l}\text { Laboratory analysis: the surface of } 20 \text { types of cloth } \\
\text { masks was characterized using the optical image } \\
\text { analysis method. The efficiency of the selected } \\
\text { cloth face masks was verified using the particle } \\
\text { counting method. }\end{array}$ & VI \\
\hline Ngonghala, et $a^{1(20)}$ & 2020/United States & $\begin{array}{l}\text { Kermack-McKendrick mathematical model: analysis } \\
\text { of the impact of control and mitigation strategies } \\
\text { at the level of the population using a mathematical } \\
\text { assessment. }\end{array}$ & VI \\
\hline O'Kelly, et al(21) & 2020/United States & $\begin{array}{l}\text { Laboratory analysis: the ability of } 20 \text { types of fabrics } \\
\text { and materials to decreasing ultrafine air particle } \\
\text { concentrations was assessed. }\end{array}$ & VI \\
\hline Rodriguez-Palacios, et al(22) & 2020/United States & $\begin{array}{l}\text { Laboratory analysis: a bacterial-suspension spray } \\
\text { simulation model of droplet ejection (mimicking a } \\
\text { sneeze) was used to quantify the extent to which } \\
\text { widely available clothing fabrics decrease the } \\
\text { dispersion of droplets on surfaces at } 1.8 \mathrm{~m} \text {, the } \\
\text { minimum distance recommended for COVID- } 19 \text {. }\end{array}$ & VI \\
\hline $\mathrm{Ma}$, et al(10) & 2020/China & $\begin{array}{l}\text { Laboratory analysis: use in the type } 403 \text { nebulizer to } \\
\text { produce aerosols with a median diameter of } 3.9 \mu \mathrm{m} \text {. }\end{array}$ & $\mathrm{VI}$ \\
\hline
\end{tabular}

Figure 2 - Description of studies found in the databases according to authors, country, year of publication, and level of evidence. Fortaleza, CE, Brazil, 2020

The particles analyzed in the studies were: monodisperse and polydisperse aerosols (20-1000 nm), Bacillus atrophaeus (0,95-1,25 $\mu \mathrm{m})$ and $B$ atrophages (23 nm), monodisperse aerosol particles (30, 100 and $500 \mathrm{~nm}$ and 1 and $2.5 \mu \mathrm{m}$ ), particles $(<5,5-10$ and $>10 \mu \mathrm{m})$, particles ( 0 to $0.8 \mu \mathrm{m})$, micro and macro bacteria $\left(3 \times 10^{6-7} \mathrm{cfu} / \mathrm{ml}\right)$, aerosols (median diameters of $3.9 \mu \mathrm{m}$ and $65 \%$ of aerosols with diameters below $5.0 \mu \mathrm{m}$ ), with a frequency of $11.1 \%$ in the studies.

The face masks included were: masks made of cotton, silk, scarf, tea towel, pillowcase, antimicrobial pillowcase, linen, vacuum cleaner bag, of cotton fabric with an exhaust valve, High-Efficiency Particulate Arrestance (HEPA) washable vacuum bag, thick felt wool, cotton, heavy fabric, folded sock, cotton quilt, felt crafts, $100 \%$ nylon, denim, cotton jersey mesh, lycra, fusible interface, and lightweight shirt. The main results are presented in Figure 3.

Table 1 presents comparisons between types of masks and their efficacy and percentage of findings. The "low protection" efficacy level included papers reporting insufficient particle filtering; "moderate protection" included papers reporting marginal/reasonable particle filtering, and the "high protection" level included papers reporting significant particle filtering. 


\begin{tabular}{|c|c|c|c|}
\hline Authors & Type of mask & Particle & Main results \\
\hline $\begin{array}{l}\text { Rengasamy; Eimer; } \\
\text { Shaffer }{ }^{(15)}\end{array}$ & Cloth masks & $\begin{array}{l}\text { Monodisperse and polydisperse } \\
\text { aerosols }(20-1000 \mathrm{~nm})\end{array}$ & $\begin{array}{l}\text { Cloth masks presented different penetration } \\
\text { values for polydisperse particles }(40-90 \%) \\
\text { and monodisperse particles }(40-97 \%), \\
\text { indicating marginal respiratory protection. }\end{array}$ \\
\hline Davies, et al ${ }^{(16)}$ & $\begin{array}{l}\text { Masks made of cotton, silk, scarf, tea towel, } \\
\text { pillowcase, antimicrobial pillowcase, vacuum } \\
\text { bag, cotton mask with an exhaust valve }\end{array}$ & $\begin{array}{l}\text { Bacillus atrophaeus }(0.95-1.25 \\
\mu \mathrm{m}) \text { e } B \text { atrófagos }(23 \mathrm{~nm})\end{array}$ & $\begin{array}{l}\text { The masks significantly decreased the } \\
\text { number of microorganisms expelled, } \\
\text { however, surgical masks are three times } \\
\text { more efficient in blocking spreading } \\
\text { compared to homemade masks. }\end{array}$ \\
\hline Macintyre, et al ${ }^{(17)}$ & Surgical and cloth face masks & Not reported & $\begin{array}{l}\text { The penetration of particles in cloth masks } \\
\text { was almost } 97 \% \text { and } 44 \% \text { in surgical } \\
\text { masks. Moisture retention, reuse of cloth } \\
\text { masks, and insufficient filtration may result } \\
\text { in an increased risk of infection. } \\
\end{array}$ \\
\hline Shakya, et al(18) & $\begin{array}{l}\text { Cloth face masks with an exhaust valve, } \\
\text { commercially available face cloth masks, } \\
\text { surgical and N95 masks. }\end{array}$ & $\begin{array}{l}\text { Monodisperse aerosol particles } \\
(30,100 \text {, and } 500 \mathrm{~nm} \text { and } 1 \text { and } \\
2.5 \mu \mathrm{m}) \text {. }\end{array}$ & $\begin{array}{l}\text { Cloth face masks are marginally beneficial } \\
\text { to protect individuals against particles } \\
<2.5 \mu \mathrm{m} \text {. }\end{array}$ \\
\hline Neupane, et al $\left.\right|^{(19)}$ & Cloth face masks & Particles $(<5,5-10$ and $>10 \mu \mathrm{m})$ & $\begin{array}{l}\text { The filtration efficiency of cloth masks } \\
\text { ranged from } 63 \% \text { to } 84 \% \text {, with a } 20 \% \\
\text { reduction after the fourth washing and } \\
\text { drying cycle. }\end{array}$ \\
\hline Ngonghala, et al ${ }^{(20)}$ & Cloth and surgical face masks. & Not reported & $\begin{array}{l}\text { Wearing masks in public is very useful to } \\
\text { minimize community spreading and burden } \\
\text { of COVID-19, provided that the coverage } \\
\text { level is high. To decrease contamination, } \\
\text { multi-layer cloth face masks are necessary } \\
\text { in association with social distancing. }\end{array}$ \\
\hline O’Kelly, et al(21) & $\begin{array}{l}\text { Cloth face masks and masks made of } \\
\text { material commonly available: HEPA* } \\
\text { washable vacuum bag, thick felted wool, } \\
\text { cotton, heavy fabric, folded sock, cotton } \\
\text { quilt, felt crafts, } 100 \% \text { nylon, denim, cotton } \\
\text { jersey mesh, lycra, fusible interface, and } \\
\text { lightweight shirt. }\end{array}$ & Particles $(0$ to $0.8 \mu \mathrm{m})$ & $\begin{array}{l}\text { Single-layer fabric blocked ultrafine } \\
\text { particles. Significantly more ultrafine } \\
\text { particles were filtered when fabric layered. } \\
\text { Various combinations of fabrics succeeded } \\
\text { in filtering similar amounts of ultrafine } \\
\text { particles when compared to surgical and } \\
\text { N95 masks. }\end{array}$ \\
\hline $\begin{array}{l}\text { Rodriguez-Palacios, } \\
\text { et al(22) }\end{array}$ & Cloth face masks & $\begin{array}{l}\text { Micro and macro bacteria: } \\
\text { Lactobacillus lactis, } L \text {. } \\
\text { plantarum, } L \text {. casei, } L \text {. } \\
\text { acidophilus, Leuconostoc } \\
\text { cremoris, Bifidobacterium } \\
\text { longum, B. breve, B. lactis, } \\
\text { Streptococcus diacetylactis and } \\
\text { Saccharomyces L. rhamnosus, } \\
\text { florentinus }\left(3 \times 10^{6-7} \text { cfu/ml) }\right.\end{array}$ & $\begin{array}{l}\text { Double-layered textiles were as efficient as } \\
\text { surgical masks/fabric in decreasing droplet } \\
\text { dispersion to }<10 \mathrm{~cm} \text { and circumferential } \\
\text { contamination area to } \sim 0.3 \% \text {. }\end{array}$ \\
\hline $\mathrm{Ma}$, et al $\mathrm{a}^{(10)}$ & $\begin{array}{l}\text { One-layer polyester fabric masks, } \\
\text { homemade face mask made of one-layer } \\
\text { polyester fabric plus four-layer kitchen paper } \\
\text { towel, surgical mask, and N95 mask. }\end{array}$ & $\begin{array}{l}\text { Aerosols (median diameters of } \\
3.9 \mu \mathrm{m} \text { ) }\end{array}$ & $\begin{array}{l}\text { N95, surgical and homemade masks } \\
\text { made of four-layer kitchen paper towel and } \\
\text { one-layer fabric potentially block } 99.98 \% \text {, } \\
97.14 \% \text {, and } 95.15 \% \text { of the virus by aerosol, } \\
\text { respectively. }\end{array}$ \\
\hline
\end{tabular}

*HEPA = High-Efficiency Particulate Arrestance

Figure 3 - Description of studies according to types of facemasks, samples, and main results. Fortaleza, CE, Brazil, 2020

Table 1 - Type of masks, effects found, and proportion of findings among the studies. Fortaleza, CE, Brazil, 2020

\begin{tabular}{|c|c|c|c|}
\hline Type of mask & Efficacy & $\begin{array}{c}\text { Number and } \\
\text { percentage of studies }\end{array}$ & Studies \\
\hline \multirow[t]{2}{*}{ Cloth facemask } & Moderate protection & $4(80 \%)$ & $\begin{array}{l}\text { Rengasamy; Eimer; Shaffer, et al }{ }^{(15)} \\
\text { Shakya, et al }{ }^{(18)} \\
\text { Neupane, et al }\left.\right|^{(19)} \\
\text { Ma, et } \mathrm{al}^{(10)}\end{array}$ \\
\hline & Poor protection & $1(20 \%)$ & Maclntyre, et al ${ }^{(17)}$ \\
\hline Cloth face mask with low coverage & Moderate protection & $1(100 \%)$ & Rodriguez-Palacios, et al(22) \\
\hline Cloth face mask with high coverage & High protection & $2(100 \%)$ & $\begin{array}{l}\text { Ngonghala, et al }{ }^{(20)} \\
\text { Rodriguez-Palacios, et al }\left.\right|^{(22)}\end{array}$ \\
\hline $\begin{array}{l}\text { Masks made of cotton, silk, scarf, tea towel, } \\
\text { pillowcase, antimicrobial pillowcase, linen, vacuum } \\
\text { bag, mixed cotton. }\end{array}$ & Moderate protection & $1(100 \%)$ & Davies, et al(16) \\
\hline $\begin{array}{l}\text { Mask made of HEPA* washable vacuum bag, thick } \\
\text { felt wool, cotton, heavy fabric, folded sock, cotton } \\
\text { quilt, felt craft, } 100 \% \text { nylon, denim, cotton jersey } \\
\text { mesh, lycra, fusible interface, and lightweight shirt. }\end{array}$ & High protection & $1(100 \%)$ & O’Kelly, et al(21) \\
\hline
\end{tabular}

*HEPA = High-Efficiency Particulate Arrestance 


\section{Discussion}

This study shows that most studies (44.4\%) were published in 2020. Of these, one was published in China and four were published in the United States of America (USA). These results are explained by the fact that these countries represent the epicenters of the new coronavirus pandemic, which encourages researchers to develop research to fight the disease. In late April, China recorded more than 84,000 confirmed cases and more than 4,600 deaths, while the USA recorded more than one million cases and more than 60,000 deaths ${ }^{(23)}$.

COVID-19 is a disease caused by a positive-sense RNA virus, with 50 to $200 \mathrm{~nm}$ in diameter ${ }^{(24)}$. Studies conducted up to mid-April did not test the efficacy of masks to absorb such particles, however, there is evidence of the absorption of monodisperse and polydisperse aerosols $(20-1000 \mathrm{~nm})^{(15)}$, Bacillus atrophaeus $(0.95-1.25 \mu \mathrm{m})$ and $B$ atrophages $(23 \mathrm{~nm})^{(16)}$, monodisperse aerosol particles $(30,100 \text { and } 500 \mathrm{~nm} \text { and } 1 \text { and } 2.5 \mu \mathrm{m})^{(18)}$, particles $<5$, 5-10 and $>10 \mu \mathrm{m}^{(19)}$, particles from 0 to $0.8 \mu \mathrm{m}^{(21)}$, micro and macro bacteria $\left(3 \times 10^{6-7} \mathrm{cfu} / \mathrm{ml}\right)^{(22)}$, and aerosols (with median diameters of $3.9 \mu \mathrm{m})^{(10)}$.

Part of the studies analyzed particles smaller than those of SARS-CoV-2, as a micrometer $(\mu \mathrm{m})$ is equivalent to 1,000 nanometers $(\mathrm{nm})$. Hence, these findings may be similar to future findings regarding viral particles of coronavirus that cause COVID-19.

Additionally, a variation between $40 \%$ and $97 \%$ of protection was found among the cloth face masks addressed in the studies included in this review. This variance is related to the type of cloth used, the number of layers, and the number of washing cycles. This finding corroborates a study conducted during the outbreak of influenza $A(\mathrm{H} 1 \mathrm{~N} 1)^{(15)}$, which identified that some fabrics present better filtration rates than others: towels and scarfs performed better than other cloth materials when testing monodisperse particles $<100 \mathrm{~nm}$ (Aquis, Pinzon and Pem America). It shows that characteristics concerning the fabric fiber (diameter, load, and density) influence in the masks' efficacy.

Studies report that the performance of cloth face masks is inferior to hospital masks (N95 and/or surgical masks); however, when double-layered, cloth masks are as efficient as hospital masks. These findings agree with the recommendations provided by the Brazilian Ministry of Health ${ }^{(25)}$ to contain the pandemic, as it suggests the population to make double-layered masks for own use. This was a measure of urgency taken in the process of preventing COVID-19 because personal protection equipment is scarce worldwide, and surgical and N95 masks should be saved for health workers who are more exposed to contamination by SARS-CoV- 2 .
In addition to Brazil, other countries have adhered to the use of homemade cloth face masks to decrease the dissemination of the COVID-19 virus, as is the case of the USA, Israel, Austria, the Czech Republic, Hong Kong, and Mongolia(26-27).

As opposed to these findings, a cluster-randomized clinical trial, conducted in the wards of a hospital in Vietnam, assessed masks wore by health workers during eight-hour shifts for four weeks and verified that cotton face masks absorb almost $97 \%$ of environmental particles while surgical masks absorb $44 \%$. Insufficient filtration is a risk for the development of infections, especially among health workers(17).

In the context of a pandemic, the use of cloth face masks by the population is valid considering that scientific evidence shows its efficiency, especially when they have high coverage(28). Additionally, according to the study developed in the USA, a combination of low-efficiency face masks combined with other preventive measures, especially social isolation, favor the control of the pandemic ${ }^{(20)}$.

As for the correct use of masks, the study conducted in Nepal shows that the efficacy of cloth masks decreases $20 \%$ after the fourth washing and drying $\mathrm{cycle}^{(19)}$. This decreased efficiency occurs because the cleaning process diminishes the microfibers in the fabric and increases the size of the pores. These data contradict ANVISA's recommendations, which indicates up to 30 washing cycles $^{(7)}$. Note that the WHO encourages the use and care of cloth masks, but does not restrict the number of washing cycles $^{(8)}$, while the Brazilian Ministry of Health recommends changing masks after signs of wear ${ }^{(25)}$.

Therefore, this review presents important scientific contributions for the health and nursing fields both in the Brazilian and international contexts, because the use of cloth face masks is one of the main preventive measures recommended by health managers and health workers to contain the dissemination of the virus in the community. Hence, this study's results provide support to strengthen the practice implemented in various countries through governmental decrees considering that part of the studies analyzed, showed moderate effectiveness in preventing respiratory infections caused by particles of similar size to SARS-CoV-2.

Note that the efficacy of the barrier provided by cloth face masks against droplets is mainly influenced by the type of fabric used, number of layers, and frequency of washings. Therefore, health workers, especially nurses, should instruct the population through social media regarding the proper use and correct washing of cloth masks to maximize and extend the protective effect of this tool for extended periods.

This study's main limitations are related to some studies' lack of information regarding the characteristics 
of the fabrics analyzed and a lack of studies addressing specific SARS-CoV-2 particles.

\section{Conclusion}

This synthesis presents knowledge regarding nine international studies, most published in 2020, using laboratory analysis. The following nanometric and micrometric substances were studied: monodisperse and polydisperse aerosols, Bacillus atrophaeus, $B$ atrophages, monodisperse aerosol particles, micro, and macro bacteria, and environmental and laboratory particles/ aerosols. Diameters ranged from $0 \mu \mathrm{m}$ to $1000 \mathrm{~nm}$.

Low coverage cloth face masks made of $100 \%$ cotton, scarf, pillowcase, antimicrobial pillowcase, linen, tea towel, and vacuum cleaner bag presented moderate protection in the process of absorbing the particles analyzed, while high coverage cloth masks made of HEPA washable vacuum bag, thick felted wool, cotton, heavy fabric, folded sock, cotton quilt, felt crafts, $100 \%$ nylon, denim, cotton jersey mesh, lycra, fusible interface, and lightweight shirt presented high protection.

Most cloth masks presented moderate absorption of micrometric and nanometric particles so that we can infer that the filtering efficacy observed in these studies will be similar to viral particles causing COVID-19. Therefore, we believe this protective equipment handcrafted according to the recommendations provided by the health authorities of each country can contribute to the prevention of coronavirus transmission in the community, as it is a preventive measure that can favor the decrease of the disease in Brazil and the world.

We emphasize the urgency and need for further studies considering the pandemic demands the establishment of evidence-based preventive measures. While new studies are not conducted, however, we suggest the use of cloth masks is recommended to the population, especially high coverage masks (more than one layer) due to their ability to provide greater protection in absorbing nanometric and micrometric particles, similar to the SARS-CoV-2 structure. Another recommendation is to discard and replace masks after the fourth washing cycle.

\section{References}

1. Moren DM, Daszak P, Taubenberger JK. Escaping Pandora's Box-Another Novel Coronavirus. N Engl J Med. [Internet]. 2020 Feb [cited Apr 5, 2020];382:1293-5. Available from: https://doi.org/10.1056/NEJMp2002106 2. Djalante R, Lassa J, Setiamarga D, Sudjatma A, Indrawan $M$, Haryanto $B$, et al. Review and analysis of current responses to COVID-19 in Indonesia: Period of January to March 2020. Prog Dis Science. [Internet].
2020 Apr [cited Apr 21, 2020];6:100091. Avaliable from: https://doi.org/10.1016/j.pdisas.2020.100091

3. Adhikari SP, Meng S, Wu YJ, Mao YP, Ye RX, Wang $\mathrm{Q}-\mathrm{Z}$, et al. Epidemiology, causes, clinical manifestation and diagnosis, prevention and control of coronavirus disease (COVID-19) during the early outbreak period: a scoping review. Infect Dis Poverty. [Internet]. 2020 Mar [cited Apr 21, 2020];9(1):29. Avaliable from: https:// doi.org/10.1186/s40249-020-00646-x

4. Gajbhiye R, Modi D, Mahale S. Pregnancy outcomes, Newborn complications and Maternal-Fetal Transmission of SARS-CoV-2 in women with COVID-19: A systematic review of 441 cases. medRxiv [Internet];2020 May [cited May 6, 2020]. Avaliable from: https://doi. org/10.1101/2020.04.11.20062356

5. Gasmi A, Noor S, Tippaitote T, Dadar M, Mensel A, Bjørklund $G$. Individual risk management strategy and potential therapeutic options for the COVID-19 pandemic. Clin Immunol. [Preprint]. 2020 Apr [cited Apr 22, 2020]. Avaliable from: https://doi.org/10.1016/j.clim.2020.108409 6. Cheng VCC, Wong SC, Chen JHK, Yip CCY, Chuang VWM, Tsang OTY, et al. Escalating infection control response to the rapidly evolving epidemiology of the coronavirus disease 2019 (COVID-19) due to SARSCoV-2 in Hong Kong. Infect Control Hosp Epidemiol. [Preprint]. 2020 Mar [cited Apr 22, 2020];5:1-6. Avaliable from: https://doi.org/10.1017/ice.2020.58

7. Agência Nacional de Vigilância Sanitária (BR). Orientações Gerais - Máscaras faciais de uso não profissional. [Internet]. 2020. [Acesso 22 abr, 2020] Disponível em: http://portal.anvisa.gov.br/documents/219201/4340788/ NT+M\%C3\%A1scaras.pdf/bf430184-8550-42cb-a9751d5e1c5a10f7

8. World Health Organization. Advice on the use of masks in the context of COVID-19: interim guidance. Geneva: World Health Organization; 2020 [cited Apr 27, 2020]. Avaliable from: https://apps.who.int/iris/ handle/10665/331693

9. Rafael RMR, Neto M, Carvalho MMB, David HMSL, Acioli $S$, Faria MGA. Epidemiologia, políticas públicas e pandemia de Covid-19: o que esperar no Brasil? Rev Enferm UERJ. [Internet]. 2020 [Acesso $22 \mathrm{abr}$ 2020];28:e49570. Disponível em: http://dx.doi. org/10.12957/reuerj.2020.49570

10. Ma QX, Shan H, Zhang HL, Li GM, Yang RM, Chen JM. Potential utilities of mask-wearing and instant hand hygiene for fighting SARS-CoV-2. J Med Virol. [Preprint]. 2020 Mar [cited Apr 23, 2020];1-5. Available from: https://doi.org/10.1002/jmv.25805

11. Souza MT, Silva MD, Carvalho R. Revisão integrativa: o que é e como fazer. Einstein [Internet]. 2010 Jan/ Mar [Acesso 23 abr 2020];8(1)102-6. Disponível em: https://doi.org/10.1590/s1679-45082010rw1134 
12. Lockwood C, Porrit K, Munn Z, Rittenmeyer L, Salmond S, Bjerrum M, et al. Chapter 2: Systematic reviews of qualitative evidence. In: Joanna Briggs Institute Reviewer's Manual. [Internet]. 2019 [cited Apr 23, 2020]. Available from: https://reviewersmanual. joannabriggs.org

13. Moher D, Liberati A, Tetzlaff J, Altman DG. Preferred Reporting Items for Systematic Reviews and MetaAnalyses: The PRISMA Statement. PLoS Med. [Internet]. 2009 Jul [cited Apr 23, 2020];6(7):e1000097. Avaliable from: http://dx.doi.org/10.1371/journal. pmed.1000097

14. Melnyk BM, Fineout-Overholt E. Evidence-based practice in nursing \& healthcare: a guide to best practice. $3^{\text {rd }}$ ed. Philadelphia: Wolters Kluwer Health; 2015.

15. Rengasamy S, Eimer B, Shaffer RE. Simple respiratory protection - evaluation of the filtration performance of cloth masks and common fabric materials against 20-1000 nm size particles. Ann Occup Hyg. [Internet]. 2010 Oct [cited Apr 24, 2020];54(7):789-98. Avaliable from: https://doi.org/10.1093/annhyg/meq044

16. Davies A, Thompson KA, Giri K, Kafatos G, Walker J, Bennett A. Testing the efficacy of homemade masks: would they protect in an influenza pandemic? Disaster Med Public Health Prep. [Inetrnet]. 2013 Aug [cited Apr 23, 2020];7(4):413-8. Avaliable from: https://doi. org/10.1017/dmp.2013.43

17. MacIntyre CR, Seale H, Dung TC, Hien NT, Nga PT, Chughtai $A A$, et al. A cluster randomised trial of cloth masks compared with medical masks in healthcare workers. BMJ Open. [Internet]. 2015 Apr [cited Apr 23, 2020];5(4):e006577. Avaliable from: https://doi. org/10.1136/bmjopen-2014-006577

18. Shakya KM, Noyes A, Kallin R, Peltier RE. Evaluating the efficacy of cloth facemasks in reducing particulate matter exposure. J Expo Sci Environ Epidemiol. [Internet]; 2017 May [cited Apr 23, 2020];27(3):3527. Avaliable from: https://doi.org/10.1038/jes.2016.42 19. Neupane BB, Mainali S, Sharma A, Giri B. Optical microscopic study of surface morphology and filtering efficiency of face masks. Peer J. [Internet] 2019 Jun [cited Apr 23, 2020];7:e7142. Available from: https:// doi.org/ 10.7717/peerj.7142

20. Ngonghala CN, Iboi E, Eikenberry S, Scotch M, MacIntyre $\mathrm{CR}$, Bonds $\mathrm{MH}$, et al. Mathematical assessment of the impact of non-pharmaceutical interventions on curtailing the 2019 novel Coronavirus. MedRxiv. [Internet]. $2020 \mathrm{Apr}$ [cited 24 Apr, 2020]. Avaliable from: https://doi.org/10.1101/2020.04.15.20066480

21. O'Kelly E, Pirog S, Ward J, Clarkson PJ. Informing Homemade Emergency Facemask Design: The Ability of Common Fabrics to Filter Ultrafine Particles. MedRxiv. [Internet]. $2020 \mathrm{Apr}$ [cited 24 Apr, 2020]. Avaliable from: https://doi.org/10.1101/2020.04.14.20065375

22. Rodriguez-Palacios A, Cominelli F, Basson A, Pizarro T, Ilic S. Textile Masks and Surface Covers - A "Universal Droplet Reduction Model" Against Respiratory Pandemics. Medrxiv. [Internet] Apr 2020 [cited 24 Apr, 2020]. Avaliable from: https://doi. org/10.1101/2020.04.07.20045617

23. Menezes PL, Garner DM, Valenti VE. Brazil is projected to be the next global covid-19 pandemic epicenter. medRxiv. [Internet]. $2020 \mathrm{Apr}$ [cited May 6, 2020]. Avaliable from: https://doi.org/10.1101/2020.04.28.20083675

24. Xu X, Chen P, Wang J, Feng J, Zhou H, Li X, et al. Evolution of the novel coronavirus from the ongoing Wuhan outbreak and modeling of its spike protein for the risk of human transmission. Sci China Life Sci. [Internet]. 2020 Jan [cited Apr 24, 2020];63:457-60. Avaliable from: https://doi.org/10.1007/s11427-020-1637-5

25. Ministério da Saúde (BR). Secretaria de Atenção Primária à Saúde. Nota Informativa No 3/2020-CGGAP/ DESF/SAPS/MS. Brasília: Ministério da Saúde; 2020 [cited Apr 26, 2020]. Avaliable from: https://www.saude. gov.br/images/pdf/2020/April/04/1586014047102Nota-Informativa.pdf

26. Tanne JH. Americans are told to wear cloth masks. BJM. [Internet]. $2020 \mathrm{Apr}$ [cited Apr 26, 2020];369:m1411. Avaliable from: https://doi.org/10.1136/bmj.m1411

27. Mahase E. Covid-19: What is the evidence for cloth masks? BMJ. [Internet]. 2020 Apr. [cited Apr 27, 2020];369:m1422. Avaliable from: https://doi. org/10.1136/bmj.m1422

28. Onur A, Emon B, Saif MTA. Performance of fabrics for home-made masks against spread of respiratory infection through droplets: a quantitative mechanistic study. MedRxiv. [Preprint]. $2020 \mathrm{Apr}$ [cited Apr 27, 2020]. Avaliable from: https://doi.org/10.1101/2020.04.19.20071779

Received: May $11^{\text {th }} 2020$ Accepted: May $28^{\text {th }} 2020$

Associate Editor: Maria Lúcia Zanetti

Copyright $\odot \mathbf{2 0 2 0}$ Revista Latino-Americana de Enfermagem This is an Open Access article distributed under the terms of the Creative Commons (CC BY).

This license lets others distribute, remix, tweak, and build upon your work, even commercially, as long as they credit you for the original creation. This is the most accommodating of licenses offered. Recommended for maximum dissemination and use of licensed materials.
Magda Milleyde de Sousa Lima

E-mail: limamilleyde@gmail.com

(D) https://orcid.org/0000-0001-5763-8791 